\title{
Correction to: Superficial radial neuropathy: an unobserved etiology of chronic dorsoradial wrist pain
}

Emmanuel Kamal Aziz Saba*

\section{Correction to: Egypt Rheumatol Rehabil 48, 29 (2021)}

https://doi.org/10.1186/s43166-021-00077-y

Following the publication of the original article [1] the author brought to our attention that an error had been introduced to the last sentence of the "Results" section of the "Abstract" during the implementation of his corrections by the typesetters.

The words "de Quervain's disease" had inadvertently been replaced by the words "was three and half fingers till the level of the distal".

The correct sentence reads: "The most common associated local wrist pathology was de Quervain's disease in 8 upper limbs (27.6\%) from 8 patients (30.8\%)".

The original article has already been revised to include the correct sentence as shown above.
Published online: 17 November 2021

\section{Reference}

1. Saba (2021) Superficial radial neuropathy: an unobserved etiology of chronic dorsoradial wrist pain. Egypt Rheumatol Rehabil 48:29. https:// doi.org/10.1186/s43166-021-00077-y original author(s) and the source, provide a link to the Creative Commons licence, and indicate if changes were made. The images or other third party material in this article are included in the article's Creative Commons licence, unless indicated otherwise in a credit line to the material. If material is not included in the article's Creative Commons licence and your intended use is not permitted by statutory regulation or exceeds the permitted use, you will need to obtain permission directly from the copyright holder. To view a copy of this licence, visit http://creativecommons.org/licenses/by/4.0/. 